\title{
The role of vitamin $D$ in pulmonary disease: COPD, asthma, infection, and cancer
}

\author{
Christian Herr ${ }^{1,3}$, Timm Greulich¹, Rembert A Koczulla1', Silke Meyer ${ }^{2}$, Tetyana Zakharkina ${ }^{1,3}$, Meret Branscheidt ${ }^{1}$, \\ Rebecca Eschmann ${ }^{1}$, Robert Bals ${ }^{1,3^{*}}$
}

\begin{abstract}
The role of vitamin D (VitD) in calcium and bone homeostasis is well described. In the last years, it has been recognized that in addition to this classical function, VitD modulates a variety of processes and regulatory systems including host defense, inflammation, immunity, and repair. VitD deficiency appears to be frequent in industrialized countries. Especially patients with lung diseases have often low VitD serum levels. Epidemiological data indicate that low levels of serum VitD is associated with impaired pulmonary function, increased incidence of inflammatory, infectious or neoplastic diseases. Several lung diseases, all inflammatory in nature, may be related to activities of VitD including asthma, COPD and cancer. The exact mechanisms underlying these data are unknown, however, VitD appears to impact on the function of inflammatory and structural cells, including dendritic cells, lymphocytes, monocytes, and epithelial cells. This review summarizes the knowledge on the classical and newly discovered functions of VitD, the molecular and cellular mechanism of action and the available data on the relationship between lung disease and VitD status.
\end{abstract}

VitD supplementation appears to be correlated with decreased total mortality [1]. In the early 1920s a group of scientists independently discovered that irradiating of certain foods with ultraviolet light renders them antirachitic [2,3] and in 1922 Elmer V. McCollum identified an antirachitic substance in cod liver oil and called it "vitamin D" [4]. While the role of VitD in calcium and bone homeostasis has been well described, its activities on other physiological and pathophysiological processes have been recognized only in the last years. Epidemiological data suggest that several lung diseases, all inflammatory in nature, may be related to activities of VitD. VitD deficiency might have a role in the development of these diseases. The underlying mechanisms how VitD metabolisms could be linked to the pathophysiology of these diseases are often complex and not fully understood. This review summarizes the role of VitD in lung diseases.

\footnotetext{
* Correspondence: robert.bals@uks.eu

1Department of Internal Medicine, Division for Pulmonary Diseases, PhilippsUniverstät Marburg, 35043 Marburg, Germany

Full list of author information is available at the end of the article
}

\section{Evolutionary aspects}

VitD and its receptors are found throughout the animal kingdom and are often linked to bone and calcium metabolisms. The fact that precursors of VitD are found in ancient organisms like krill and phytoplankton that existed unchanged for at least 750 million years [5] highlights its importance in physiologic and homeostatic processes.

Variants of VitD and its receptors have been identified in higher terrestrial vertebrates like humans [6], rodents [7], birds [8], amphibia [9], reptiles [10], as well as in zebrafish [11]. These animals possess a calcified skeleton and depend on a functional VitD hormone system for calcium and phosphorus homeostasis. Surprisingly, functional VitD receptors (VDRs) have also been found in lampreys, an ancient vertebrate that lacks a calcified skeleton [12]. VDRs were also identified in animals with a naturally impoverished VitD status like the subterranean mole rat [13] and a frugivorous nocturnal mammal, the Egyptian fruit bat Cavaleros [14]. VitD precursors have been found in ancient organisms like phytoplankton and zooplankton, some of which exist unchanged for at least 750 million years $[5,15]$. Functional VitD hydroxylases have also been characterized in bacteria like strains of actinomyces [16,17] and streptomyces $[18,19]$. The 
precursors of VitD in those organisms may function as a natural sunscreen to protect the host against UV-radiation, since the absorption spectra of pro-vitamin D and their photoproducts overlap with the absorption maxima of DNA, RNA, and proteins [20].

\section{Role of VitD in bone metabolism}

VitD, which is photosynthesized in the skin or has been derived from nutrition, is metabolized two times, before it mediates its calcemic effects by binding to the nuclear VitD receptor (VDR) [21,22](Figure 1). The metabolizing enzymes belong to a group of cytochrome P450 hydroxylases, which can be found in eukaryotes, bacteria, fungi and plants. In the human liver, the first hydroxylation of VitD on C-25 is performed by mitochondrial 25hydroxylase enzymes (gene names: CYP27A1 [23] and/ or CYP2R1 [24]) that both belong to the cytochrome $\mathrm{P} 450$ family. The inactive $25-(\mathrm{OH})$-vitamin $\mathrm{D}_{3}(25-(\mathrm{OH})$ $\mathrm{D}_{3}$ ) metabolite is further hydroxylated at position $1 \alpha$ by the mitochondrial cytochrome P450 enzyme 25-hydroxyvitamin-D-1 $\alpha$-hydroxylase (gene name: CYP27B1) and converted to the bioactive $1 \alpha, 25$-dihydroxyvitamin $\mathrm{D}$ $\left(1,25-(\mathrm{OH})_{2} \mathrm{D}_{3}\right)$. This latter step is mainly localized to the proximal kidney tubule [25], however, many other cell types, including lung epithelial cells, are capable to perform this reaction [26-29]. The serum concentration of $25-(\mathrm{OH}) \mathrm{D}_{3}$ reflects the organism's VitD supply [30]. In the blood, VitD and the inactive, relatively stable 25$(\mathrm{OH}) \mathrm{D}_{3}$ metabolite are bound in $99 \%$ to the vitamin $\mathrm{D}$ binding protein (DBP) [31]. DBP polymorphisms (Gc phenotype) are related to the DBP concentration and VitD status [32]. The $1 \alpha$-hydroxylation of $25-(\mathrm{OH}) \mathrm{D}_{3}$ is upregulated by parathyroid hormone $(\mathrm{PTH})$, calcitonin, low calcium- and phosphate levels as well as by estrogen, prolactin and growth hormone [33]. Calcitonin, cortisol, high phosphate levels and $25-(\mathrm{OH}) \mathrm{D}_{3}$ suppress the 25-hydroxyvitamin D-1 $\alpha$-hydroxylase activity [34]. $1,25-(\mathrm{OH})_{2} \mathrm{D}_{3}$ itself works as its own negative feedback regulator by induction of the expression of a 24-hydydroxylase (CYP24A1). Further, 1,25- $(\mathrm{OH})_{2} \mathrm{D}_{3}$ decreases the production and secretion of PTH. PTH synthesis and secretion is induced by decreased serum calcium levels, which are detected by the calcium sensing receptor of the parathyroid gland. PTH effects renal tubular reabsorption of calcium, renal production of 1,25- $(\mathrm{OH})$ ${ }_{2} \mathrm{D}_{3}$ and promotes osteoclastogenesis [35].

$1,25-(\mathrm{OH})_{2} \mathrm{D}_{3}$ is essential for the development and maintenance of the growth plate, chondrocyte growth, and the mineralised bone [21]. 1,25- $(\mathrm{OH})_{2} \mathrm{D}_{3}$ modulates the osteoclastogenesis by regulation of the receptor activator of nuclear factor kappa B (RANK), RANK ligand (RANKL) and the soluble receptor osteoprotegerin

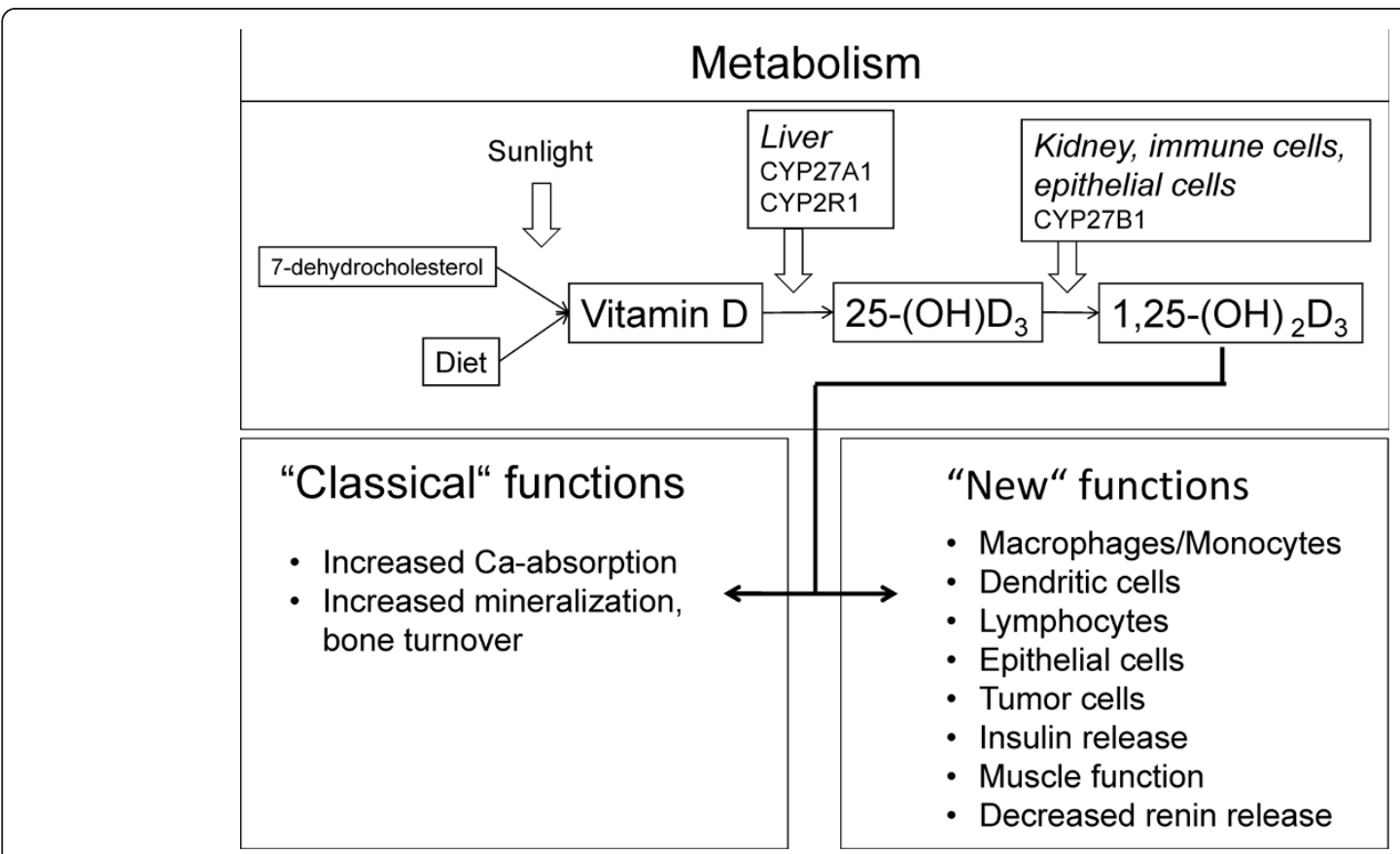

Figure 1 Metabolism and effects of VitD. VitD can be obtained from food or from synthesis in the skin under exposure to light. The precursor is hydroxylated cytochrome P450 25-hydroxylase enzymes CYP27A1 and/or CYP2R1 and subsequently by the cytochrome P450 enzyme 25hydroxyvitamin D-1 $\alpha$-hydroxylase (CYP27B1) and converted to the bioactive 1,25-(OH) ${ }_{2} \mathrm{D}_{3}$, which has role in $\mathrm{Ca}$ and bone metabolism and, in addition, in several other biological processes. Of note, bioactive $1,25-(\mathrm{OH})_{2} \mathrm{D}_{3}$ can also be generated in lung epithelia cells and monocytes/ macrophages. 
(OPG) [36]. It increases the expression of RANKL on the osteoblast surface, which supports maturation of progenitor and mature osteoclasts, and it inhibits OPG expression, which binds RANKL and prevents RANK mediated osteoclastogenesis [37].

VitD deficiency causes the development of an imbalanced calcium- and phosphate-homeostasis and the occurrence of the bone diseases osteopenia, osteoporosis, rickets, and osteomalacia with a subsequently increased fracture risk [38]. The $25-(\mathrm{OH}) \mathrm{D}_{3}$ serum concentration is directly associated with bone mineral densitys. VitD deficiency has several causes including inadequate sun exposure (and loss of functional capacity of the skin especially in the elderly), limited renal and hepatic function or insufficient intestinal resorption [39]. In VitD deficiency, the feedback on the PTH gene promoter is lacking resulting in parathyroid hyperplasia, hyperparathyroidism, and a mineralization defect of the bone.

$1,25-(\mathrm{OH})_{2} \mathrm{D}_{3}$ regulates many target genes by binding to the VDR: approximately $3 \%$ of the mouse and human genome is regulated via the VitD pathway [40]. As nongenomic action of VitD in chondrocytes, it increases the membrane-lipid turnover, prostaglandin production and protease activity, leading to bone matrix modification and calcification. Additionally to the expression of VDR in bone and multiple tissues, the presence of $1 \alpha$-hydroxylase in cells of several extrarenal tissues such as bone as well as skin, prostate, the respiratory and gastrointestinal tract, strongly suggest that VitD impacts on processes beyond the calcium and bone metabolism.

\section{Role of VitD in immunity and host defense}

More than a century ago (1849), the British physician C. J.B. Williams described the use of cod liver oil in the treatment of tuberculosis. He reported that among his tuberculosis patients, 206 out of 234 showed a "marked and unequivocal improvement" after treatment with cod liver oil [41]. Since then manifold functions of VitD have been discovered, indicating that VitD regulates many cellular processes and is potentially involved in the development of many diseases. Since the discovery of VDRs in a variety of cells of the adaptive immune system such as B- and T-lymphocytes [42,43], there have been numerous reports about the immunomodulatory activities of VitD.

Cellular studies revealed that VitD modulates the activity of various defense and immune cells including monocytes, macrophages, lymphocytes, or epithelial cells:

- Monocytes/macrophages: Low serum concentrations of VitD in patients with rickets correlate with decreased phagocytic activity of macrophages [44] that could be reversed by supplementation with $1,25-(\mathrm{OH})_{2} \mathrm{D}_{3}$ [45]. Antimicrobial activity of macrophages against $M$. tuberculosis is increased in the presence of $25-(\mathrm{OH}) \mathrm{D}_{3}$ after stimulation with mycobacterial ligands. Mycobacterial activation of toll-like receptor-2 (TLR-2) leads to an increased expression of VDR and CYP27B that results in an increased conversion of $25-(\mathrm{OH}) \mathrm{D}_{3}$ to $1,25-(\mathrm{OH})_{2} \mathrm{D}_{3}$ and subsequent expression of the antimicrobial peptide cathelicidin via VDR $[46,47]$.

- B lymphocytes: It has been shown that 1,25-(OH) ${ }_{2} \mathrm{D}_{3}$ plays a role in $\mathrm{B}$ cell homeostasis by the inhibition of proliferation and induction of apoptosis of activated $\mathrm{B}$ cells [48]. 1,25- $(\mathrm{OH})_{2} \mathrm{D}_{3}$ inhibits the differentiation of $B$ lymphocytes to plasma cells and memory B cells. These mechanisms may contribute to the pathogenesis of B-lymphocyte related diseases like systemic lupus erythematosus (SLE). Patients with SLE have significant lower serum concentration of both $25-(\mathrm{OH}) \mathrm{D}_{3}$ and $1,25-(\mathrm{OH})_{2} \mathrm{D}_{3}[49,50]$.

- T lymphocytes: A well-established function of VitD within the adaptive immune system is its ability to modulate $\mathrm{T}$ lymphocyte proliferation and function. The biologically active $1,25-(\mathrm{OH})_{2} \mathrm{D}_{3}$ inhibits proliferation of $\mathrm{T}_{\mathrm{H}}$ lymphocytes [51] and shifts the expression of cytokines from a $\mathrm{T}_{\mathrm{H}} 1$ based response towards a $\mathrm{T}_{\mathrm{H}} 2$ based profile [52,53]. Although 1,25$(\mathrm{OH})_{2} \mathrm{D}_{3}$ might be able to involve direct effects on $\mathrm{T}$ lymphocytes through the support of differentiation of regulatory $\mathrm{T}$ cells, current data indicate that 1,25 $(\mathrm{OH})_{2} \mathrm{D}_{3}$ exerts its influence on the adaptive immune response by modulating the functions of dendritic cells (DCs). Regulatory $\mathrm{T}$ cells seem to be activated by VitD with skewing of the Th1/Th2 balance towards Th2 [54]. Of note, there is evidence for and against the role of VitD in Th2 biased diseases [55], which will be discussed in more detail in the asthma section below.

- Dendritic cells: The response of DCs to 1,25-(OH) ${ }_{2} \mathrm{D}_{3}$ is restricted to myeloic DC, that express a different set of TLRs and cytokines than plasmacytoic DCs, which showed no tolerogenic response to 1,25$(\mathrm{OH})_{2} \mathrm{D}_{3}$ [56]. 1,25- $(\mathrm{OH})_{2} \mathrm{D}_{3}$ inhibits the maturation of DCs and enhances the expression of cytokines like IL-10, thereby $1,25-(\mathrm{OH})_{2} \mathrm{D}_{3}$ induces tolerance through the suppression of $\mathrm{T}_{\mathrm{H}} 1$ lymphocyte development and the induction of regulatory $\mathrm{T}$ cells [57].

- Epithelial cells: Airway epithelial cell express enzymes of the VitD metabolism and are capable to convert the precursor $25-(\mathrm{OH}) \mathrm{D}_{3}$ into the active $1,25-(\mathrm{OH})_{2} \mathrm{D}_{3}$ from $[29,58]$. They are an important source of $1,25-(\mathrm{OH})_{2} \mathrm{D}_{3}$ that induces the expression of cathelicidin or CD14 by cells of the innate immune system. $1,25-(\mathrm{OH})_{2} \mathrm{D}_{3}$ converted by airway 
epithelial cells is able to modulate the inflammatory profile after a viral infection by blocking the poly(I: C) induced chemokine and cytokine production while maintaining the antiviral activity [28,59]. As epithelial cells are primary targets of respiratory pathogens and cathelicidin has antibacterial and antiviral activity, a seasonal decrease of VitD-dependent epithelial host defense could contribute to increased numbers of lower respiratory tract infection (RTI) during winter.

\section{Roles of VitD in pulmonary diseases}

VitD has complex effects on pulmonary cell biology and immunity with impact on inflammation, host defense, wound healing, repair, and other processes. While the knowledge on direct mechanistic links between VitD and lung diseases is limited, a number of epidemiological and experimental are available that highlight the relevance of this connection.

\section{a) Asthma}

A connection between VitD status and asthma has been considered since many years. VitD deficiency has been blamed as one cause of increased asthma prevalence in the last decades [60]. VDR variants were found to be associated with asthma in patient cohorts [61]. A recent clinical investigation showed that high VitD levels are associated with better lung function, less airway hyperresponsiveness and improved glucocorticoid response [62]. A population-based study suggested that lower VitD levels are associated with increased requirements for inhaled corticosteroids in children [63]. Vitamin D insufficiency is common in this children with mild-tomoderate persistent asthma and is associated with higher odds of severe exacerbation [64]. Epidemiologic studies have also shown that maternal VitD intake during pregnancy protects from wheezing in childhood $[65,66]$. In contrast, also data exist that children whose mothers had high VitD levels in pregnancy had an increased risk of eczema and asthma [67], suggesting that the time point of Vit D supplementation seems to determine the susceptibility to atopic disease. On the experimental level in a murine asthma model, the VDR is necessary for the development of an allergic airway inflammation [68].

The underlying mechanisms how VitD modulates the pathogenesis of asthma are not clear. VitD may protect from developing respiratory infections that could serve as trigger for a deterioration of asthma [69]. VitD may also modulate the function of various immune cells as outlined above. Interestingly, application of VitD is potentially capable to overcome the poor glucocorticoid responsiveness in severe asthmatics by upregulation of IL-10 production from CD4+ T cells [70].

\section{b) Chronic obstructive lung disease (COPD)}

The connection between VitD status and COPD has attracted attention in the recent months. This is based on data from observational studies that determined levels of VitD in COPD patients. Black and colleagues examined data from the NHANES III data set (cross-sectional survey of 14091 adults in the US). After adjustment for potential confounders, a strong relationship between serum levels of VitD and lung function ( $\mathrm{FEV}_{1}$ and FVC) was found [71]. Although a significant correlation with airway obstruction could not be found, the observed dose-response relationship may suggest a causal link [72]. A number of studies have reported on $25-(\mathrm{OH}) \mathrm{D}_{3}$ levels in COPD patients. Forli et al. found VitD deficiency (in this study defined as below $20 \mathrm{ng} / \mathrm{ml}$ ) in more than $50 \%$ of a cohort waiting for lung transplantation [73]. In an outpatient study on patients with COPD in Denmark, 68\% of the participants had osteoporosis or osteopenia [74]. A recent study showed that VitD deficiency is highly prevalent in COPD and correlates with variants in the VitD binding gene [75]. There are several factors that could account for VitD deficiency in COPD patients: Poor diet, a reduced capacity of aging skin for VitD synthesis, reduced outdoor activity and therefore sun exposure, an increased catabolism by glucocorticoids, impaired activation because of renal dysfunction, and a lower storage capacity in muscles or fat due to wasting [76]. Many steps of the VitD pathway (intake, synthesis, storage, metabolism) can potentially be disturbed in COPD patients.

A single nucleotide polymorphism (SNP) of the DBP was shown to be associated with a decreased risk of COPD by a mechanism that is unclear [77]. Similar SNPs in the gene coding for DBP may influence the level of circulating $25-(\mathrm{OH}) \mathrm{D}_{3}$ and $1,25-(\mathrm{OH})_{2} \mathrm{D}_{3}$ $[32,78]$. Therefore it has been hypothesized that their protective role might be mediated by the bioavailability of $1,25-(\mathrm{OH})_{2} \mathrm{D}_{3}$ [79].

The mechanisms that link VitD biology with the development of COPD are largely speculative:

1) The association of VitD deficiency and reduced lung function could depend on the calcemic effects of VitD. The vital capacity and total lung capacity was found to decline with an increasing number of thoracic vertebral fractures as a direct consequence of VitD deficiency [80]. Nuti et al. observed 3030 ambulatory COPD patients and found a strong association between COPD severity and fractures [81]. Kyphosis related to osteoporosis caused limitation in rib mobility and inspiratory muscle function and correlated with a reduction in $\mathrm{FEV}_{1}$ and FVC [82]. The altered properties of the thoracic skeleton could result in failure of the respiratory muscles contributing to the pathophysiology of COPD. 
2) VitD deficiency could result in altered host defense of the lung with subsequent growth of an abnormal flora that triggers inflammation. Acute exacerbations of COPD are an important cause of hospitalization and lead to a faster decline in $\mathrm{FEV}_{1}$ [83]. Exacerbations are triggered by viruses, bacteria, atypical strains, or a combination of these [84-87]. Potential bacterial pathogens are detected in about $50 \%$ of exacerbations. A therapeutic consequence would be the up-regulation of the innate immune defense system. Wang and colleagues demonstrated that genes coding for the antimicrobial peptide cathelicidin (LL-37/hCAP-18) are regulated by VDRE-containing promoters [88]. In cultured monocytes, a local increase of the 1,25D3-VDR complex stimulates the production of LL-37, resulting in an improved intracellular eradication of Mycobacterium tuberculosis [47]. The data demonstrated that the activation of TLRs on human monocytes triggers a microbicidal pathway that is dependent on both the endogenous production and action of $1,25-(\mathrm{OH})_{2} \mathrm{D}_{3}$ through the VDR.

3) The effect of VitD on extracellular matrix homeostasis not only in bone tissue, but also within the lung may have a role in COPD development. Boyan et al. found VitD to be an autocrine regulator of extracellular matrix turnover and growth factor release via matrix metalloproteinases [89]. Matrix metalloproteinasis-9 (MMP-9) has been shown to be elevated in induced sputum of COPD patients and a causative role has been suggested in the development of COPD [90]. VitD also to attenuates TNFalpha induced upregulation of MMP-9 in keratinocytes [91]. VitD deficiency may lead to a reduced attenuation of MMP-9 activity resulting in enhanced degradation of lung parenchyma.

Recently, it has been recognized that COPD is a systemic disease [92] with several closely related comorbidities [93]. Interestingly, VitD deficiency is associated with a equivalent spectrum of diseases including coronary heart disease, cancer, inflammatory disease and infection [76]. Comorbidities of COPD such as reduced bone mineral density and skeletal muscle weakness $[94,95]$ have been associated with low VitD serum concentrations.

\section{c) Infection}

\section{Tuberculosis}

A number of candidate polymorphisms of VitD receptor (VDR) and VitD binding protein (DBP) have been identified that modulate the development of tuberculosis [96]. The genotype tt (detected by Taq I digestion) is associated with decreased risk of tuberculosis. As described by Lewis et al. [97], larger studies are required to determine whether VDR polymorphisms play a role in genetic susceptibility to tuberculosis worldwide. In a recent meta-analysis, low serum levels of $25-(\mathrm{OH}) \mathrm{D}_{3}$ were associated with a higher risk of active tuberculosis. The pooled effect size was 0.68 with $95 \%$ CI $0.43-0.93$. The authors concluded that the low VitD levels increase the risk of active tuberculosis [98]. There are several randomized, double-blind, placebo-controlled trials of VitD treatment in tuberculosis. In one study, 67 tuberculosis patients were randomized to receive VitD $(0.25$ $\mathrm{mg} /$ day) or placebo during the 6 initial week of $\mathrm{Tb}$ treatment [99]. A statistical significant difference in sputum conversion (i.e, the change of detectable to no detectable Mycobacteria in the sputum) was discovered in favor of the VitD group (100\% vs. $76,7 \%$; $p=0.002)$. Another trial was conducted in 192 healthy adult tuberculosis contacts in London, United Kingdom [100]. Participants were randomized to receive a single oral dose of $2.5 \mathrm{mg}$ VitD or placebo and followed up at 6 weeks. VitD supplementation significantly enhanced the ability of participants' whole blood to restrict BCG-lux luminescence after 24 hours in vitro as compared with placebo, but did not affect antigen-stimulated IFN-gamma secretion after 96 hours. As the innate immune responses are mobilized more rapidly than acquired immune responses, the authors interpreted the 24- and 96-hour results as indicators of innate and acquired responses, respectively. They concluded that vitamin D supplementation may primarily enhance innate responses to mycobacterial infection. Wejse et al. included 365 tuberculosis patients starting anti-tuberculotic treatment in Guinea Bissau [101]. 281 patients completed the 12 month follow-up. The intervention was 100,000 IU cholecalciferol or placebo at inclusion and again at 5 and 8 months after start of treatment. Reduction in TBscore and sputum smear conversion rates did not differ among VitD and placebo treated patients. Taken those data together there seems to be a benefit of VitD in the treatment of tuberculosis but this could not be reproduced in the largest study so far.

\section{Respiratory tract infections (RTI)}

RTI are more common in the winter period than during summertime. Because the food intake of VitD is insufficient, sunlight exposure is the primary determinant of VitD status in humans, and seasonal differences in VitD level in human are well documented [76]. During the winter months, there is insufficient UV-B exposure to produce sufficient amounts of VitD. Wintertime VitD insufficiency may explain seasonal variation in influenza and other, mostly viral, RTIs [102]. Ginde et al. performed a secondary analysis of the Third National Health and Nutrition Examination Survey, hypothesizing an association between $25-(\mathrm{OH}) \mathrm{D}_{3}$ level and self- 
reported upper respiratory tract infections (URTI) in 18883 subjects [103]. After adjusting for season, body mass index, smoking history, asthma, and COPD, lower $25-(\mathrm{OH}) \mathrm{D}_{3}$ levels were independently associated with recent URTI. In patients with respiratory tract diseases (asthma and COPD) the association between $25-(\mathrm{OH}) \mathrm{D}_{3}$ level and URTI seemed to be even stronger (OR, 5.67 and 2.26, respectively). Avenell and colleagues used data from the RECORD trial (VitD in secondary prevention of osteoporotic fractures; $n=5292$ ) [104]. In a "per protocol" analysis, a trend towards a benefit of VitD vs. placebo was detected, though not statistically significant. Despite the large number of patients in these studies, restrictions arise from the retrospective data analysis. A prospective cohort study included 800 young Finnish men serving on a military base [105]. Their serum 25$(\mathrm{OH}) \mathrm{D}_{3}$ was measured in the beginning of a 6 month observational period. Subjects with low $25-(\mathrm{OH}) \mathrm{D}_{3}$ levels had significantly more days of absence from duty due to respiratory infection than did control subjects $(\mathrm{p}=$ 0.004). In a case control study a total of 150 children (80 cases, 70 controls) was enrolled [106]. Low serum 25$(\mathrm{OH}) \mathrm{D}_{3}(\leq 22.5 \mathrm{nmol} / \mathrm{l})$ was associated with a significantly higher odds ratio for having severe acute lower respiratory tract infections $(\mathrm{p}<0.001)$. These studies support an role of VitD in the development of lung infection.

However, in a recent clinical trial, $\mathrm{Li}-\mathrm{Ng}$ et al. randomized 162 adults to $50 \mu \mathrm{g}$ VitD (2000 IU) daily or placebo for 12 weeks. Using a questionnaire they recorded the incidence and severity of upper RTI symptoms. Although VitD serum levels increased significantly in the VitD treated group (vs. no change in the placebo group), there was no benefit of VitD supplementation in decreasing the incidence or severity of symptomatic URTI [107]. This may be explained by the relatively low number of subjects. Furthermore, the time period of 12 weeks was probably too short to show any effect. Taken together, there is growing evidence for a protective role of VitD in the development of RTI but high quality randomized clinical trials within a sufficiently high number of patients and for a sufficient period of time are missing. In a recently published trial, the supplementation of $1500 \mathrm{E}$ VitD per day resulted in deceases incidence of influenza A by $64 \%$ [69].

\section{d) Cancer}

A number of studies suggest that low levels of VitD are associated with an up to $50 \%$ increased risk of colon, prostate, or breast cancer $[76,108]$. As an example, a recent nested case-control study showed that pre-diagnostic levels of VitD are inversely correlated with the risk of colon cancer [109]. For lung cancer, the picture is not clear at the present time. While TaqI polymorphism of the VDR gene appears to be a risk factor for lung cancer
[110], low levels of VitD were only a cancer risk factor in subgroups, i.e., in women and young individuals [111]. In patients with diagnosed lung cancer, there was no main effect of VitD level on overall survival [112]. In preclinical animal models using carcinogen (NNK)-induced lung carcinogenesis, application of $1,25-(\mathrm{OH})_{2} \mathrm{D}_{3}$ resulted in decreased cancer growth [113].

\section{Conclusions}

VitD has a number of activities in addition to its effect on calcium and bone homeostasis and influences process such as immune regulation, host defense, inflammation, or cell proliferation. VitD deficiency is potentially involved in a number of lung disease. Several hurdles must be overcome to validate the benefit of VitD-based therapies: 1) Basic mechanisms are not clear and the involved molecular pathways are likely difficult to identify because VitD impacts on a variety of biological processes in parallel. 2) Conclusive data from interventional studies are missing for many disease entities. 3) Since VitD has been used for many years, the pharmaceutical industry might hesitate in starting a development program. Nevertheless, the data available indicate that VitD could be beneficial for the prevention or therapy of important lung diseases.

\section{List of abbreviations}

1,25- $(\mathrm{OH})_{2} \mathrm{D}_{3}$ : 1a: 25-dihydroxyvitamin $\mathrm{D} ; 25-(\mathrm{OH}) \mathrm{D}_{3}$ : $\mathrm{D}_{3} 25-(\mathrm{OH})$-vitamin $\mathrm{D}_{3}$; TLR: toll like receptor; VitD: vitamin D;

\section{Acknowledgements}

This work was supported by the Deutsche Forschungsgemeinschaft (DFG) to R.B. (Ba 1641/12 and SFB/TR 22 (A8)) and the Kompetenznetz Asthma/COPD (Competence Network for Asthma/COPD funded by the Federal Ministry of Education and research (FKZ 01Gl0881-0888 (SP4/12) to RB.

\section{Author details}

${ }^{1}$ Department of Internal Medicine, Division for Pulmonary Diseases, PhilippsUniverstät Marburg, 35043 Marburg, Germany. ${ }^{2}$ Department of Internal Medicine, Division of Endocrinology \& Diabetology, Department of Internal Medicine, University Hospital Marburg, 35043 Marburg, Germany.

${ }^{3}$ Department of Pulmonology, University of the Saarland, 66421 Homburg Saar, Germany.

\section{Authors' contributions}

RB developed the concept of the review, all authors contributed in writing and reviewing the paper. All authors read and approved the final manuscript.

\section{Competing interests}

The authors declare that they have no competing interests.

Received: 3 May 2010 Accepted: 18 March 2011

Published: 18 March 2011

\section{References}

1. Autier P, Gandini S: Vitamin D supplementation and total mortality: a meta-analysis of randomized controlled trials. Arch Intern Med 2007, 167:1730-1737.

2. Goldblatt H, Soames KM: The Supplementary Value of Light Rays to a Diet Graded in its Content of Fat-Soluble Organic Factor. Biochem J 1923, 17:622-629. 
3. Steenbock H: The Induction of Growth Promoting and Calcifying Properties in a Ration by Exposure to Light. Science 1924, 60:224-225.

4. McCollum EV, Pitz W, Simmonds N, Becker JE, Shipley PG, Bunting RW: The effect of additions of fluorine to the diet of the rat on the quality of the teeth. 1925. Studies on experimental rickets. XXI. An experimental demonstration of the existence of a vitamin which promotes calcium deposition. 1922. The effect of additions of fluorine to the diet of the rat on the quality of the teeth. 1925. J Biol Chem 2002, 277:E8.

5. Holick MF: Evolution and function of vitamin D. Recent Results Cancer Res 2003, 164:3-28

6. Baker AR, McDonnell DP, Hughes M, Crisp TM, Mangelsdorf DJ, Haussler MR, et al: Cloning and expression of full-length CDNA encoding human vitamin D receptor. Proc Natl Acad Sci USA 1988, 85:3294-3298.

7. Burmester JK, Wiese RJ, Maeda N, DeLuca HF: Structure and regulation of the rat 1,25-dihydroxyvitamin D3 receptor. Proc Natl Acad Sci USA 1988, 85:9499-9502.

8. Lu Z, Hanson K, DeLuca HF: Cloning and origin of the two forms of chicken vitamin D receptor. Arch Biochem Biophys 1997, 339:99-106.

9. Li YC, Bergwitz C, Juppner H, Demay MB: Cloning and characterization of the vitamin D receptor from Xenopus laevis. Endocrinology 1997, 138:2347-2353.

10. Laing CJ, Fraser DR: The vitamin D system in iguanian lizards. Comparative Biochemistry and Physiology Part B: Biochemistry and Molecular Biology 1999, 123:373-379.

11. Ciesielski F, Rochel N, Mitschler A, Kouzmenko A, Moras D: Structural investigation of the ligand binding domain of the zebrafish VDR in complexes with 1alpha,25(OH)2D3 and Gemini: purification, crystallization and preliminary X-ray diffraction analysis. J Steroid Biochem Mol Biol 2004, 89-90:55-59.

12. Whitfield GK, Dang HT, Schluter SF, Bernstein RM, Bunag T, Manzon LA, et al: Cloning of a functional vitamin $D$ receptor from the lamprey (Petromyzon marinus), an ancient vertebrate lacking a calcified skeleton and teeth. Endocrinology 2003, 144:2704-2716.

13. Sergeev IN, Buffenstein $R$, Pettifor JM: Vitamin $D$ receptors in a naturally vitamin D-deficient subterranean mammal, the naked mole rat (Heterocephalus glaber): biochemical characterization. Gen Comp Endocrinol 1993, 90:338-345.

14. Cavaleros M, Buffenstein R, Ross FP, Pettifor JM: Vitamin D metabolism in a frugivorous nocturnal mammal, the Egyptian fruit bat (Rousettus aegyptiacus). Gen Comp Endocrinol 2003, 133:109-117.

15. Copping AM: Origin of vitamin D in cod-liver oil: vitamin D content of zooplankton. Biochem J 1934, 28:1516-1520.

16. Sasaki J, Miyazaki A, Saito M, Adachi T, Mizoue K, Hanada K, et al: Transformation of vitamin D3 to 1 alpha,25-dihydroxyvitamin D3 via 25hydroxyvitamin D3 using Amycolata sp. strains. Appl Microbiol Biotechnol 1992, 38:152-157.

17. Yasutake $Y$, Fujii $Y$, Cheon WK, Arisawa A, Tamura T: Crystallization and preliminary X-ray diffraction studies of vitamin D3 hydroxylase, a novel cytochrome P450 isolated from Pseudonocardia autotrophica. Acta Crystallogr Sect F Struct Biol Cryst Commun 2009, 65:372-375.

18. Sasaki J, Mikami A, Mizoue K, Omura S: Transformation of 25- and 1 alphahydroxyvitamin D3 to 1 alpha, 25-dihydroxyvitamin D3 by using Streptomyces sp. strains. Appl Environ Microbiol 1991, 57:2841-2846.

19. Sawada N, Sakaki T, Yoneda S, Kusudo T, Shinkyo R, Ohta M, et al: Conversion of vitamin D3 to 1alpha,25-dihydroxyvitamin D3 by Streptomyces griseolus cytochrome P450SU-1. Biochem Biophys Res Commun 2004, 320:156-164.

20. MacLaughlin JA, Anderson RR, Holick MF: Spectral character of sunlight modulates photosynthesis of previtamin D3 and its photoisomers in human skin. Science 1982, 216:1001-1003.

21. St-Arnaud R: The direct role of vitamin D on bone homeostasis. Arch Biochem Biophys 2008, 473:225-230.

22. Janssens W, Lehouck A, Carremans C, Bouillon R, Mathieu C, Decramer M: Vitamin $D$ beyond bones in chronic obstructive pulmonary disease: time to act. Am J Respir Crit Care Med 2009, 179:630-636.

23. Sawada N, Sakaki T, Ohta M, Inouye K: Metabolism of vitamin D(3) by human CYP27A1. Biochem Biophys Res Commun 2000, 273:977-984.

24. Cheng JB, Levine MA, Bell NH, Mangelsdorf DJ, Russell DW: Genetic evidence that the human CYP2R1 enzyme is a key vitamin D 25hydroxylase. Proc Natl Acad Sci USA 2004, 101:7711-7715.
25. Negri AL: Proximal tubule endocytic apparatus as the specific renal uptake mechanism for vitamin D-binding protein/25-(OH)D3 complex. Nephrology (Carlton ) 2006, 11:510-515.

26. Cross HS, Kallay E, Lechner D, Gerdenitsch W, Adlercreutz H, Armbrecht HJ: Phytoestrogens and vitamin D metabolism: a new concept for the prevention and therapy of colorectal, prostate, and mammary carcinomas. J Nutr 2004, 134:1207S-1212S

27. Penna G, Adorini L: 1 Alpha,25-dihydroxyvitamin D3 inhibits differentiation, maturation, activation, and survival of dendritic cells leading to impaired alloreactive T cell activation. J Immunol 2000, 164:2405-2411.

28. Hansdottir S, Monick MM, Hinde SL, Lovan N, Look DC, Hunninghake GW: Respiratory epithelial cells convert inactive vitamin $D$ to its active form: potential effects on host defense. J Immunol 2008, 181:7090-7099.

29. Yim S, Dhawan P, Ragunath C, Christakos S, Diamond G: Induction of cathelicidin in normal and CF bronchial epithelial cells by 1,25dihydroxyvitamin D(3). J Cyst Fibros 2007, 6:403-410.

30. Holick MF: Vitamin D status: measurement, interpretation, and clinical application. Ann Epidemiol 2009, 19:73-78.

31. Kochupillai N: The physiology of vitamin D: current concepts. Indian J Med Res 2008, 127:256-262

32. Lauridsen AL, Vestergaard P, Hermann AP, Brot $C$, Heickendorff $L$, Mosekilde $L$, et al: Plasma concentrations of 25-hydroxy-vitamin $D$ and 1,25-dihydroxy-vitamin $D$ are related to the phenotype of Gc (vitamin Dbinding protein): a cross-sectional study on 595 early postmenopausal women. Calcif Tissue Int 2005, 77:15-22.

33. Kann P: [Vitamin D and osteoporosis. Pathogenesis-therapy]. Dtsch Med Wochenschr 1994, 119:1479-1485.

34. Zhong Y, Armbrecht HJ, Christakos S: Calcitonin, a regulator of the 25hydroxyvitamin D3 1alpha-hydroxylase gene. J Biol Chem 2009, 284:11059-11069.

35. Anderson PH, O'Loughlin PD, May BK, Morris HA: Quantification of mRNA for the vitamin D metabolizing enzymes CYP27B1 and CYP24 and vitamin $\mathrm{D}$ receptor in kidney using real-time reverse transcriptasepolymerase chain reaction. J Mol Endocrinol 2003, 31:123-132.

36. Hofbauer LC, Heufelder AE: Role of receptor activator of nuclear factorkappaB ligand and osteoprotegerin in bone cell biology. J Mol Med 2001, 79:243-253.

37. Kochupillai N: The physiology of vitamin D: current concepts. Indian J Med Res 2008, 127:256-262.

38. Holick MF, Chen TC: Vitamin D deficiency: a worldwide problem with health consequences. Am J Clin Nutr 2008, 87:1080S-1086S

39. Lips P: Vitamin D deficiency and secondary hyperparathyroidism in the elderly: consequences for bone loss and fractures and therapeutic implications. Endocr Rev 2001, 22:477-501.

40. Uitterlinden AG, Fang Y, van Meurs JB, Pols HA, van Leeuwen JP: Genetics and biology of vitamin D receptor polymorphisms. Gene 2004, 338:143-156.

41. Williams CJB: Cod-liver Oil in Phthisis. Lond J Med 1849, 1:1-18

42. Provvedini DM, Tsoukas CD, Deftos LJ, Manolagas SC: 1,25dihydroxyvitamin D3 receptors in human leukocytes. Science 1983, 221:1181-1183.

43. Provvedini DM, Tsoukas CD, Deftos LJ, Manolagas SC: 1 alpha,25Dihydroxyvitamin D3-binding macromolecules in human B lymphocytes: effects on immunoglobulin production. J Immunol 1986, 136:2734-2740.

44. Stroder J, Kasal P: Evaluation of phagocytosis in rickets. Acta Paediat Scand 1970, 59:288-292.

45. Bar-Shavit Z, Noff D, Edelstein S, Meyer M, Shibolet S, Goldman R: 1,25dihydroxyvitamin D3 and the regulation of macrophage function. Calcif Tissue Int 1981, 33:673-676.

46. Stenger S, Modlin RL: Control of Mycobacterium tuberculosis through mammalian Toll-like receptors. Curr Opin Immunol 2002, 14:452-457.

47. Liu PT, Stenger S, Li H, Wenzel L, Tan BH, Krutzik SR, et al: Toll-like receptor triggering of a vitamin D-mediated human antimicrobial response. Science 2006, 311:1770-1773.

48. Chen S, Sims GP, Chen XX, Gu YY, Chen S, Lipsky PE: Modulatory effects of 1,25-dihydroxyvitamin D3 on human B cell differentiation. J Immunol 2007, 179:1634-1647.

49. Adams JS, Liu PT, Chun R, Modlin RL, Hewison M: Vitamin D in defense of the human immune response. Ann N Y Acad Sci 2007, 1117:94-105. 
50. Adorini L, Penna G: Control of autoimmune diseases by the vitamin D endocrine system. Nat Clin Pract Rheumatol 2008, 4:404-412.

51. Lemire JM, Adams JS, Kermani-Arab V, Bakke AC, Sakai R, Jordan SC: 1,25Dihydroxyvitamin D3 suppresses human T helper/inducer lymphocyte activity in vitro. J Immunol 1985, 134:3032-3035.

52. Lemire JM, Archer DC, Beck L, Spiegelberg HL: Immunosuppressive actions of 1,25-dihydroxyvitamin D3: preferential inhibition of Th1 functions. J Nutr 1995, 125:1704S-1708S.

53. Boonstra A, Barrat FJ, Crain C, Heath VL, Savelkoul HF, O'Garra A: 1alpha,25Dihydroxyvitamin $\mathrm{d} 3$ has a direct effect on naive CD4(+) T cells to enhance the development of Th2 cells. J Immunol 2001, 167:4974-4980.

54. Smolders J, Thewissen M, Peelen E, Menheere P, Cohen Tervaert JW, Damoiseaux J, et al: Vitamin D status is positively correlated with regulatory $T$ cell function in patients with multiple sclerosis. PLOS ONE 2009, 4:e6635.

55. Ginde AA, Sutherland ER: Vitamin D in asthma: panacea or true promise? J Allergy Clin Immunol 2010, 126:59-60.

56. Penna G, Amuchastegui S, Giarratana N, Daniel KC, Vulcano M, Sozzani S, et al: 1,25-Dihydroxyvitamin D3 selectively modulates tolerogenic properties in myeloid but not plasmacytoid dendritic cells. J Immunol 2007, 178:145-153.

57. Penna G, Adorini L: 1 Alpha,25-dihydroxyvitamin D3 inhibits differentiation, maturation, activation, and survival of dendritic cells leading to impaired alloreactive T cell activation. J Immunol 2000, 164:2405-2411.

58. Hansdottir S, Monick MM, Hinde SL, Lovan N, Look DC, Hunninghake GW: Respiratory epithelial cells convert inactive vitamin $D$ to its active form: potential effects on host defense. J Immunol 2008, 181:7090-7099.

59. Hansdottir S, Monick MM, Lovan N, Powers L, Gerke A, Hunninghake GW: Vitamin D decreases respiratory syncytial virus induction of NF-kappaBlinked chemokines and cytokines in airway epithelium while maintaining the antiviral state. J Immunol 2010, 184:965-974.

60. Litonjua AA, Weiss ST: Is vitamin D deficiency to blame for the asthma epidemic? J Allergy Clin Immunol 2007, 120:1031-1035.

61. Poon AH, Laprise C, Lemire M, Montpetit A, Sinnett D, Schurr E, et al: Association of vitamin $D$ receptor genetic variants with susceptibility to asthma and atopy. Am J Respir Crit Care Med 2004, 170:967-973.

62. Sutherland ER, Goleva E, Jackson LP, Stevens AD, Leung DY: Vitamin D Levels, Lung Function and Steroid Response in Adult Asthma. Am J Respir Crit Care Med 2010, 181:699-704.

63. Brehm JM, Celedon JC, Soto-Quiros ME, Avila L, Hunninghake GM, Forno $E$, et al: Serum vitamin $D$ levels and markers of severity of childhood asthma in Costa Rica. Am J Respir Crit Care Med 2009, 179:765-771

64. Brehm JM, Schuemann B, Fuhlbrigge AL, Hollis BW, Strunk RC, Zeiger RS, et al: Serum vitamin $D$ levels and severe asthma exacerbations in the Childhood Asthma Management Program study. J Allergy Clin Immunol 2010, 126:52-58.

65. Camargo CA Jr, Rifas-Shiman SL, Litonjua AA, Rich-Edwards JW, Weiss ST, Gold DR, et al: Maternal intake of vitamin D during pregnancy and risk of recurrent wheeze in children at 3 y of age. Am J Clin Nutr 2007, 85:788-795.

66. Devereux G, Litonjua AA, Turner SW, Craig LC, McNeill G, Martindale S, et al: Maternal vitamin D intake during pregnancy and early childhood wheezing. Am J Clin Nutr 2007, 85:853-859.

67. Gale CR, Robinson SM, Harvey NC, Javaid MK, Jiang B, Martyn CN, et al: Maternal vitamin D status during pregnancy and child outcomes. Eur J Clin Nutr 2008, 62:68-77.

68. Wittke A, Weaver V, Mahon BD, August A, Cantorna MT: Vitamin D receptor-deficient mice fail to develop experimental allergic asthma. J Immunol 2004, 173:3432-3436.

69. Urashima M, Segawa T, Okazaki M, Kurihara M, Wada Y, Ida H: Randomized trial of vitamin $D$ supplementation to prevent seasonal influenza $A$ in schoolchildren. Am J Clin Nutr 2010, 91:1255-1260.

70. Xystrakis E, Kusumakar S, Boswell S, Peek E, Urry Z, Richards DF, et al: Reversing the defective induction of IL-10-secreting regulatory $T$ cells in glucocorticoid-resistant asthma patients. J Clin Invest 2006, 116:146-155.

71. Black PN, Scragg R: Relationship between serum 25-hydroxyvitamin d and pulmonary function in the third national health and nutrition examination survey. Chest 2005, 128:3792-3798.
72. Wright RJ: Make no bones about it: increasing epidemiologic evidence links vitamin D to pulmonary function and COPD. Chest 2005, 128:3781-3783

73. Forli L, Halse J, Haug E, Bjortuft O, Vatn M, Kofstad J, et al: Vitamin D deficiency, bone mineral density and weight in patients with advanced pulmonary disease. J Intern Med 2004, 256:56-62.

74. Jorgensen NR, Schwarz P, Holme I, Henriksen BM, Petersen LJ, Backer V: The prevalence of osteoporosis in patients with chronic obstructive pulmonary disease: a cross sectional study. Respir Med 2007, 101:177-185.

75. Janssens W, Bouillon R, Claes B, Carremans C, Lehouck A, Buysschaert I, et al: Vitamin D Deficiency is Highly Prevalent in COPD and Correlates with Variants in the Vitamin D Binding Gene. Thorax 2010, 65:215-20.

76. Holick MF: Vitamin D deficiency. N Engl J Med 2007, 357:266-281.

77. Schellenberg D, Pare PD, Weir TD, Spinelli JJ, Walker BA, Sandford AJ: Vitamin D binding protein variants and the risk of COPD. Am J Respir Crit Care Med 1998, 157:957-961.

78. Taes YE, Goemaere S, Huang G, Van PI, De BD, Verhasselt B, et al: Vitamin D binding protein, bone status and body composition in communitydwelling elderly men. Bone 2006, 38:701-707.

79. Janssens W, Lehouck A, Carremans C, Bouillon R, Mathieu C, Decramer M: Vitamin D Beyond Bones in Chronic Obstructive Pulmonary Disease: Time to Act. Am J Respir Crit Care Med 2009, 179:630-636.

80. Leech JA, Dulberg C, Kellie S, Pattee L, Gay J: Relationship of lung function to severity of osteoporosis in women. Am Rev Respir dis 1990, 141:68-71.

81. Nuti R, Siviero P, Maggi S, Guglielmi G, Caffarelli C, Crepaldi G, et al: Vertebral fractures in patients with chronic obstructive pulmonary disease: the EOLO Study. Osteoporos Int 2009, 20:989-998.

82. Schlaich C, Minne HW, Bruckner T, Wagner G, Gebest HJ, Grunze M, et al: Reduced pulmonary function in patients with spinal osteoporotic fractures. Osteoporos Int 1998, 8:261-267.

83. Niewoehner DE: The impact of severe exacerbations on quality of life and the clinical course of chronic obstructive pulmonary disease. Am J Med 2006, 119:38-45

84. Camargo CA Jr, Ginde AA, Clark S, Cartwright CP, Falsey AR, Niewoehner DE: Viral pathogens in acute exacerbations of chronic obstructive pulmonary disease. Intern Emerg Med 2008, 3:355-359.

85. Mogulkoc N, Karakurt S, Isalska B, Bayindir U, Celikel T, Korten V, et al: Acute purulent exacerbation of chronic obstructive pulmonary disease and Chlamydia pneumoniae infection. Am J Respir Crit Care Med 1999, 160:349-353.

86. Lieberman D, Lieberman D, Printz S, Ben-Yaakov M, Lazarovich Z, Ohana B, et al: Atypical pathogen infection in adults with acute exacerbation of bronchial asthma. Am J Respir Crit Care Med 2003, 167:406-410.

87. Papi A, Luppi F, Franco F, Fabbri LM: Pathophysiology of exacerbations of chronic obstructive pulmonary disease. Proc Am Thorac Soc 2006, 3:245-251

88. Wang $T$, Nestel FP, Bourdeau V, Nagai Y, Wang Q, Liao J, et al: Cutting edge: 1,25-dihydroxyvitamin D3 is a direct inducer of antimicrobial peptide gene expression. J Immunol 2004, 173:2909-2912.

89. Boyan $\mathrm{BD}$, Wong KL, Fang M, Schwartz Z: 1alpha,25(OH)2D3 is an autocrine regulator of extracellular matrix turnover and growth factor release via ERp60 activated matrix vesicle metalloproteinases. J Steroid Biochem Mol Biol 2007, 103:467-472

90. Culpitt SV, Rogers DF, Traves SL, Barnes PJ, Donnelly LE: Sputum matrix metalloproteases: comparison between chronic obstructive pulmonary disease and asthma. Respir Med 2005, 99:703-710.

91. Bahar-Shany K, Ravid A, Koren R: Upregulation of MMP-9 production by TNFalpha in keratinocytes and its attenuation by vitamin D. J Cell Physiol 2010, 222:729-737.

92. Sin DD, Man SF: Systemic inflammation and mortality in chronic obstructive pulmonary disease. Can J Physiol Pharmacol 2007, 85:141-147.

93. Walter RE, Wilk JB, Larson MG, Vasan RS, Keaney JF Jr, Lipinska I, et al: Systemic inflammation and COPD: the Framingham Heart Study. Chest 2008, 133:19-25.

94. Gosselink R, Troosters T, Decramer M: Peripheral muscle weakness contributes to exercise limitation in COPD. Am J Respir Crit Care Med 1996, 153:976-980

95. Bischoff-Ferrari HA, Dawson-Hughes B, Willett WC, Staehelin HB, Bazemore MG, Zee RY, et al: Effect of Vitamin D on falls: a meta-analysis. Jama 2004, 291:1999-2006. 
96. Leandro AC, Rocha MA, Cardoso CS, Bonecini-Almeida MG: Genetic polymorphisms in vitamin D receptor, vitamin D-binding protein, Tolllike receptor 2, nitric oxide synthase 2, and interferon-gamma genes and its association with susceptibility to tuberculosis. Braz J Med Biol Res 2009, 42:312-322.

97. Lewis SJ, Baker I, Davey SG: Meta-analysis of vitamin D receptor polymorphisms and pulmonary tuberculosis risk. Int J Tuberc Lung Dis 2005, 9:1174-1177.

98. Nnoaham KE, Clarke A: Low serum vitamin D levels and tuberculosis: a systematic review and meta-analysis. Int J Epidemiol 2008, 37:113-119.

99. Nursyam EW, Amin Z, Rumende CM: The effect of vitamin D as supplementary treatment in patients with moderately advanced pulmonary tuberculous lesion. Acta Med Indones 2006, 38:3-5.

100. Martineau AR, Wilkinson RJ, Wilkinson KA, Newton SM, Kampmann B, Hall BM, et al: A single dose of vitamin D enhances immunity to mycobacteria. Am J Respir Crit Care Med 2007, 176:208-213.

101. Wejse C, Gomes VF, Rabna P, Gustafson P, Aaby P, Lisse IM, et al: Vitamin D as Supplementary Treatment for Tuberculosis - A Double-blind Randomized Placebo-controlled Trial. Am J Respir Crit Care Med 2009, 179:843-50.

102. Cannell JJ, Vieth R, Umhau JC, Holick MF, Grant WB, Madronich S, et al: Epidemic influenza and vitamin D. Epidemiol Infect 2006, 134:1129-1140.

103. Ginde AA, Mansbach JM, Camargo CA Jr: Association between serum 25hydroxyvitamin $\mathrm{D}$ level and upper respiratory tract infection in the Third National Health and Nutrition Examination Survey. Arch Intern Med 2009, 169:384-390.

104. Avenell A, Cook JA, Maclennan GS, Macpherson GC: Vitamin D supplementation to prevent infections: a sub-study of a randomised placebo-controlled trial in older people (RECORD trial, ISRCTN 51647438). Age Ageing 2007, 36:574-577.

105. Laaksi I, Ruohola JP, Tuohimaa P, Auvinen A, Haataja R, Pihlajamaki $\mathrm{H}$, et al: An association of serum vitamin $D$ concentrations $<40 \mathrm{nmol} / \mathrm{L}$ with acute respiratory tract infection in young Finnish men. Am J Clin Nutr 2007, 86:714-717.

106. Wayse V, Yousafzai A, Mogale K, Filteau S: Association of subclinical vitamin $D$ deficiency with severe acute lower respiratory infection in Indian children under 5 y. Eur J Clin Nutr 2004, 58:563-567.

107. Li-Ng M, Aloia JF, Pollack S, Cunha BA, Mikhail M, Yeh J, et al: A randomized controlled trial of vitamin D3 supplementation for the prevention of symptomatic upper respiratory tract infections. Epidemiol Infect 2009, 137:1-9.

108. Garland CF, Gorham ED, Mohr SB, Garland FC: Vitamin D for cancer prevention: global perspective. Ann Epidemiol 2009, 19:468-483.

109. Jenab M, Bueno-de-Mesquita HB, Ferrari $P$, van Duijnhoven FJ, Norat $T$, Pischon T, et al: Association between pre-diagnostic circulating vitamin D concentration and risk of colorectal cancer in European populations:a nested case-control study. Bmj 2010, 340:b5500.

110. Dogan I, Onen HI, Yurdakul AS, Konac E, Ozturk C, Varol A, et al: Polymorphisms in the vitamin $D$ receptor gene and risk of lung cancer. Med Sci Monit 2009, 15:BR232-BR242.

111. Kilkkinen A, Knekt P, Heliovaara M, Rissanen H, Marniemi J, Hakulinen T, et al: Vitamin D status and the risk of lung cancer: a cohort study in Finland. Cancer Epidemiol Biomarkers Prev 2008, 17:3274-3278.

112. Heist RS, Zhou W, Wang Z, Liu G, Neuberg D, Su L, et al: Circulating 25hydroxyvitamin D, VDR polymorphisms, and survival in advanced nonsmall-cell lung cancer. J Clin Oncol 2008, 26:5596-5602.

113. Mernitz H, Smith DE, Wood RJ, Russell RM, Wang XD: Inhibition of lung carcinogenesis by 1alpha,25-dihydroxyvitamin D3 and 9-cis retinoic acid in the $A / J$ mouse model: evidence of retinoid mitigation of vitamin $D$ toxicity. Int J Cancer 2007, 120:1402-1409.

doi:10.1186/1465-9921-12-31

Cite this article as: Herr et al:: The role of vitamin D in pulmonary disease: COPD, asthma, infection, and cancer. Respiratory Research 2011 $12: 31$.

\section{Submit your next manuscript to BioMed Central and take full advantage of:}

- Convenient online submission

- Thorough peer review

- No space constraints or color figure charges

- Immediate publication on acceptance

- Inclusion in PubMed, CAS, Scopus and Google Scholar

- Research which is freely available for redistribution 